\title{
Origins of Lead Glaze Technology of the Ceramics of Kazan Kremlin
}

\section{Rezida Khramchenkova}

PhD in Physics, Senior Researcher, Kazan Federal University, Kazan, Russian Federation, Institute of Archaeology named after A. Kh. Khalikov of the Academy of Sciences of the Republic of Tatarstan, Kazan, Russian Federation; rezidahram@mail.ru

\section{Airat Sitdikov}

PhD, Doctor in History, Director of the Institute, Kazan Federal University, Kazan, Russian Federation, Institute of Archaeology named after A. Kh. Khalikov of the Academy of Sciences of the Republic of Tatarstan, Kazan, Russian Federation; sitdikov_a@mail.ru

\section{Polina Kaplan}

PhD in Biology, Associate Professor, Kazan Federal University, Kazan, Russian Federation, Institute of Archaeology named after A. Kh. Khalikov of the Academy of Sciences of the Republic of Tatarstan, Kazan, Russian Federation; gpolina33@yandex.ru

\section{Azgar Mukhamadiev}

PhD, Doctor in History, Full Professor, Kazan Federal University, Kazan, Russian Federation ncai@mail.ru

\section{Juriy Zeleneev}

PhD, Doctor in History, Associate Professor, Mari State University, Yoshkar-Ola, Russian Federation

\section{Evgenij Kazakov}

PhD, Doctor in History, Chief Researcher, Institute of Archaeology named after A. Kh. Khalikov of the Academy of Sciences of the Republic of Tatarstan, Kazan, Russian Federation; epkaz@mail.ru

\section{Doi:10.5901/mjss.2015.v6n6s5p297}

\section{Abstract}

Relevance of the studied problem is conditioned by a possibility to recovery information on the time and place of vessels production that allows to set the directions of trade relations and to establish a level of technologies development and features of vocational schools. The article studies the fragments of glazed ceramic pottery found on the territory of Kazan Kremlin from 1994 to 2001. The main research method of a problem was the method of the emission spectrum analysis. Study of the element glaze composition showed that it is made of the so-called "lead" compounding and has a chemical composition similar to ceramics from the large production centers that existed during various periods: Kadikalesi in Turkey (12th -13th centuries) and in the cities of the Crimea of the 13th -14th centuries. The conducted researches show continuity of production technologies of glazed ceramics of different schools.

Keywords: lead glaze, compounding, source of raw materials, micro impurities.

\section{Introduction}

Samples of glazed ceramic vessels are among the number of expressive findings of the archaeological monuments possessing significant information. Glazed ceramics with different structures was found in the beddings of the Kazan Khanate dated back to the $14^{\text {th }}-16^{\text {th }}$ centuries as a result of archeologists' researches on the territory of Kazan Kremlin in the 1990s (Khalikov, 1989). More than a half of the items are imported ceramics; another part consists of fragments of glazed ware of two types: red ware with blue glaze and white and red ware with green and brown glaze. A preliminary 
research of three ceramic fragments was conducted for identification of the most appropriate analytical method (Sitdikov \& Khramchenkova, 2015). According to these researches, the emission spectrum analysis that allows defining the main, minor and trace elements as well appeared to be the most informative method.

Studying of the glazed ceramics can give invaluable information about the time and a place of vessels production. It allows setting the directions of trade relations, to establish a level of development of technologies and to define the features of vocational schools. However, more reliable information about vocational schools can be received after conducting a study of the glaze chemical composition. Determination of glaze composition allows us to set both the features of compound and raw materials. Currently, there are a lot of data on element structure of glazed ceramics of different origin (Forster et. al., 2001; Bulgakov, 2005; Koval, 2009). The knowledge of compounding allows looking for the analogues coming from craft provinces of different regions in Europe and Asia. In this regard, the objective of this work was to study the chemical composition of ceramics from the excavations of Kazan Kremlin.

The study of the glaze composition of 33 samples from the excavations of Kazan Kremlin, 9 archaeological samples from the Crimea and 2 samples from Bulgarians is carried out in the presented work. Almost all the fragments are covered with glaze which foundation acts as lead. The content of lead is about $25-66 \%$. In order to identify analogies the authors carried out the comparative analysis. It showed that the similar chemical composition on macro- and trace elements is typical for glaze of archaeological fragments found in the large centers of production of glazed pottery in Turkey and the Crimea. These trade shops existed in earlier time: in the $12^{\text {th }}-13^{\text {th }}$ centuries in the Turkish settlement Kadikalesi in Turkey and in the settlements of the Crimean peninsula of the $13^{\text {th }}-14^{\text {th }}$ centuries.

\section{Materials and Methods}

The mapping of finds through Kazan Kremlin territory allows revealing places of concentration of similar glazed ceramics. 52 samples from the total number come from excavations at the Khansky Yard. Their concentration in this area means that exactly representatives of Khansky' administration was the main consumers of ceramics studied in work.

48 fragments of the total number are connected with the period of the Kazan Khanate. There are 5 fragments from the late period of the Golden Horde. The rest of finds has no stratigraphic referencing or is derived. The ratio of products from the processed beddings most likely assumes their penetration from layers of the Khanate period. Samples of fragments of the studied ceramics are shown in Fig. 1.

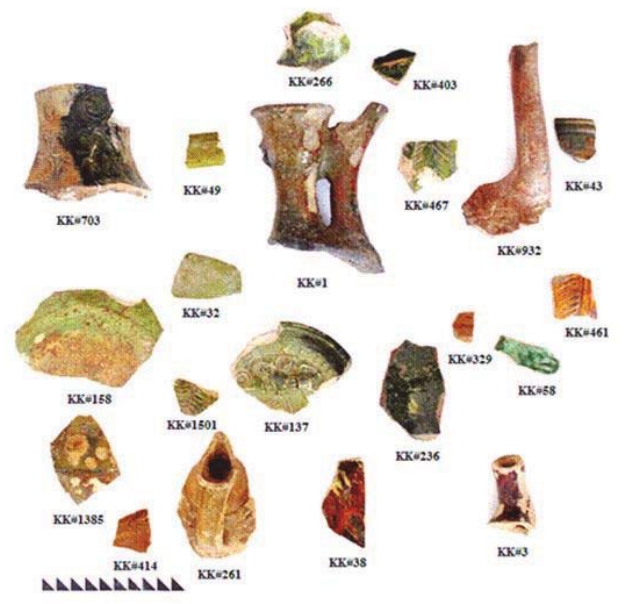

Figure 1. Fragments of glazed ceramics from the excavations in Kazan Kremlin

The detailed morphological description of the studied samples is given in the work (Sitdikov and Khramchenkova, 2015). Researches showed that $63 \%$ of ceramics is made of white ware with green glaze, $16 \%$ of red ware with green glaze, and $14 \%$ of red ware with blue glaze, $7 \%$ of white and red ware with brown glaze. According to comparison with the analytical data of X-ray fluorescence analysis emission spectroscopy was the most informative analysis (Sitdikov and 
Khramchenkova, 2015). This method allows defining simultaneously about 40 elements, as well as major, minor and trace elements. It was necessary to separate $50 \mathrm{mg}$ of the glaze from ceramics for the emission spectrum analysis. This factor is the most negative because it leads to destruction of integrity of a sample. However, taking into account the low cost of the analysis, also from the standpoint of reliability, sensitivity and informative value, this method is rather attractive for the study of archaeological artifacts in that case when inconsiderable selection of a sample is allowed. Accordingly, samples were studied in this research by the method of the emission spectrum analysis for detection of glaze composition features of different groups of ceramic.

Entity of technique. The sample of $25 \mathrm{mg}$ is burned from the carbon electrode crater in an alternating current arc to evaporate. Exposition time for easily volatile elements is about 30 seconds at a current of $8 \mathrm{~A}$ then the part of a diaphragm is blocked and a sample is burned up at a current of 18A. The spectrum obtained with a diffraction spectrograph DFS-458 is recorded on a photo plate PFS-03. A working reticle of the spectrograph No. 3 is 1800 pieces in a mm with the resolution $0,6 \mathrm{~nm}$. Photo plates are shown and fixed in standard solutions. The received spectrograms are recorded by the MF-2 spectrophotometer. The studied samples are analyzed by the method of 3 standards. Calculation of concentrations is made by standard computer program. The average of the two determinations is the result of the analysis.

It should be noted that the study did not test the chemical composition of ceramics. It is rather capacity material, the study of which is expected in the future.

\section{Results and Discussion}

The results of analytical researches are given in Table 1. Samples of the Kazan ceramics have codes №KK. These tables show that the pottery was covered (or glazed) by the so-called lead glaze with the content of lead between $25 \%$ and $66 \%$. There is a low content of tin practically for all samples. Most samples have the low content of calcium and magnesium $-<1 \%$. It means that sand with a minimum calcium component was used for the production of glaze. The aluminium content is rather high and equals 3,95\% - 8,54\%. It indicates that kaolin, clay or feldspar also were the part of glaze.

The color of glaze is received by traditional methods. The blue color is determined by the addition of 1-3\% copper, green color is caused by the presence of $0,26-2 \% \mathrm{Cu}^{2+}$ (Wedepohl et. al., 1995), brown glaze has a high content of iron > $3 \%$.

According to the analysis, the studied glaze can be divided into 8 conditional groups. Each group is characterized by a high content of certain trace elements.

1. high content of nickel (> $300 \mathrm{ppm}$ ) and vanadium (> 100ppm)

2. high content of vanadium (> 100ppm)

3. high content of antimony (>100ppm)

4. high content of vanadium (>100ppm).

5. high content of antimony and nickel (> 100ppm).

6. high content nickel (> $100 \mathrm{ppm})$ and low antimony .

7. high content of nickel (>100 ppm) and bismuth (>10ppm)

8. high content antimony (>100 ppm) and bismuth (>10ppm).

As it was noted above, the authors also conducted research of 9 fragments of the Crimean glazed ceramics. As known there were large centers for production of glazed ceramics in the Crimea in the $13^{\text {th }}-14^{\text {th }}$ centuries. This ceramics was not chosen accidentally as a sample. The color palette of samples of the Crimean peninsula is very close to the Kazan samples of green, brown and yellow. In addition, samples of the Crimean ceramics are found in a large numbers at the excavations of the Bolgar ancient settlement (Tatarstan) in layers of the $13^{\text {th }}-14^{\text {th }}$ centuries. Analytical results for the Crimean samples are given in Table 1. Researches showed that the Crimean glaze contains lead as a composition component, as well as the Kazan ceramic glaze. Analogues of the Crimean ceramics by a chemical composition are available for each of the above-mentioned groups. Thus, identity of structures is observed both for macro - and trace elements. The only difference can be noted for calcium and boron. The content of these elements is higher for the Crimean ceramic than in the Kazan fragments. It demonstrates the sources variety of raw materials of "non lead" components of glaze. The high content of boron in the Crimean ceramics can be explained by the presence of this element in the Crimean sand or clay.

In 2013, the authors had an opportunity to explore the work of sepai from the State Bolgar memorial estate. These attributes of production of glazed ceramics were used as supports during roasting glazed ware, and they are dating by the first half of the $14^{\text {th }}$ century. There were glassy sags on the artifacts. Chemical composition of the glassy material has 
also been studied and given in the lower part of the Tables 1 and 2. There are also shown the results of the component composition of turquoise glaze of sphere bell (it is thick-walled vessel which has the height of 10-15 centimeter) from the Bolgar ancient city excavation. Lead content in it is similar to the Crimean glaze (43\%), however, the tin content is about $3 \%$, and natrium content is about $6 \%$. It indicates that the glaze was prepared according to a recipe that differs from the Crimean by adding soda or ash.

Studying of the obtained analytical data showed that the manufacturing technology of a glazed layer on ceramic vessels from excavations of Kazan Kremlin is similar to the Crimean technology. A very thin layer of white engobe was done before putting glaze on pottery. The composition of engobe from a sample of Kazan Kremlin (\#1) and the Crimean glaze (\# 2) is given in Tables 1 and 2. White clay with the low content of calcium was used as engobe for Kazan ceramics. White clay was also used for the Crimean ceramics but with a mixture of calcium.

\begin{tabular}{|c|c|c|c|c|c|c|c|c|c|c|c|c|c|c|}
\hline samples & & $\mathrm{CuO}$ & PbO & $\mathrm{SnO}_{2}$ & $\mathrm{MnO}$ & $\mathrm{TOO}_{2}$ & $\mathrm{P}_{2} \mathrm{O}_{3}$ & $\mathrm{CxO}$ & $\mathrm{Fe}_{2} \mathrm{O}_{3}$ & $\mathrm{ALO}_{3}$ & $K_{2}=0$ & $\mathrm{MgO}$ & $\mathrm{N}=0$ & $\mathrm{SxO}_{2}$ \\
\hline KK \# \#137 & \multirow[t]{2}{*}{ engobe } & 0,018 & 2,37 & 0,025 & 0,058 & 0,36 & 0,62 & 0,73 & 1,519 & 18,3 & 1,53 & 0,57 & 0,17 & 73,77 \\
\hline$C$ minea $S$ & & 0,046 & 2,88 & 0,0006 & 0,058 & 0,61 & 0,1 & 3,07 & 2,78 & 23,54 & 1,39 & $0,7 \pi$ & 0,62 & 64,62 \\
\hline KK \#49 & \multirow[t]{5}{*}{ group 1} & 1,17 & 33,58 & 0,0044 & 0,035 & 0,36 & 0,17 & 0,79 & 128 & 5,47 & 0,88 & 0,1 & 0,42 & \\
\hline KK \# 703 & & 0,42 & 36,64 & 0,035 & 0,027 & 0,24 & 0,95 & 0,97 & 0,38 & 6,74 & 128 & 0,23 & 0,36 & 51,47 \\
\hline$C$ minea 6 & & 0,49 & 27,96 & 0,031 & 0,072 & 0,42 & 0,078 & 4,65 & 229 & 8,6 ⿹ & 1,14 & 1,55 & 0,54 & 51,96 \\
\hline KK \#105 & & $0, \mathscr{R}$ & 47,25 & 0,017 & 0,043 & 0,47 & 0,085 & 0,7 & 0,76 & 7,11 & 0,98 & 0,69 & 0,26 & 40,26 \\
\hline KK \#47 & & 0,58 & 49,86 & 0,016 & 0,035 & 0,38 & 0,047 & 0,42 & 1,05 & 7,32 & 0,93 & 0,17 & 0,26 & 38,79 \\
\hline KK \#467 & \multirow[t]{7}{*}{ grouq 2} & 0,72 & 38,88 & 0,028 & 0,025 & 0,3 & 0,44 & 0,42 & 0,5 & 6,05 & 0,64 & 0,12 & 0,19 & 51,25 \\
\hline KK \#403 & & 1,01 & 25,12 & 0,16 & 0,075 & 0,52 & 0,14 & 3,68 & 1,43 & 7,87 & 0,98 & 2,14 & 0,51 & 56,22 \\
\hline Crinea 26 & & 0,15 & 40,55 & 0,0035 & 0,055 & 0,64 & 0,084 & 8,39 & 5,65 & $8,7 x$ & 1,39 & 1,16 & 0,46 & 32,46 \\
\hline KK $\$ 42$ & & 0,21 & 25,53 & 0,067 & 0,035 & 0,95 & 0,87 & 1,74 & 4,86 & 8,36 & 1,33 & 1,06 & 0,49 & 54,37 \\
\hline KK \#1ra & & 0,061 & 25,88 & 0,11 & 0,04 & 0,97 & 0,25 & 1,42 & 1,18 & 3,78 & 1,67 & 1,18 & 0,46 & 62,86 \\
\hline KK \#266 & & 0,33 & 42,01 & 0,057 & 0,044 & 0,55 & 1,68 & 1,53 & 4,58 & 7,94 & 1,33 & 0,78 & 0,46 & 38,54 \\
\hline KK \#137 & & $0, \infty$ & 49,96 & 0,052 & 0,027 & 0,32 & 0,16 & 0,32 & 0,44 & 5,68 & 0,75 & 0,085 & 0,11 & 41,12 \\
\hline KK \#43 & \multirow[t]{10}{*}{ grous 3} & 0,012 & 35,96 & 0,000 & 0,13 & 0,23 & 0,24 & 026 & 1,34 & 5,36 & 0,94 & 0,063 & 0,075 & 55,11 \\
\hline Crimea 10 & & 0,20 & 45,04 & 0,0075 & 0,046 & 0,43 & 0,033 & 5,32 & 5,56 & 4,84 & 0,98 & 0,79 & 0,46 & 36,38 \\
\hline KK \#932 & & 0,008 & 42,12 & $0, \infty 41$ & 0,041 & 0,25 & 0,42 & 0,77 & 4,43 & 5,29 & 0,87 & 0,31 & 0,36 & 44,94 \\
\hline KK \#311 & & 0,19 & 51,44 & 0,013 & 0,027 & 0,28 & 0,36 & 0,22 & 028 & 5,54 & 1,15 & 0,12 & 0,036 & 40,02 \\
\hline KK \#1501 & & 0,38 & 41,53 & 0,039 & 0,033 & 1,45 & 1,49 & 1,61 & 1,05 & 8,16 & 1,02 & 0,64 & 0,22 & 42,23 \\
\hline Crimea 5I & & 0,18 & 42,59 & 0,061 & 0,048 & 0,87 & 0,054 & 4,15 & 1,35 & 7,84 & 1,92 & 1,29 & Q, & 38,95 \\
\hline KK \#1S5 & & 0,41 & 49,89 & 0,031 & 0,035 & 1,27 & 0,99 & 1,54 & 1,07 & 7,14 & 0,87 & 1,16 & 0,45 & 35,05 \\
\hline KK \#32 & & 0,81 & 45,12 & 0,028 & 0,05 & 0,39 & 0,28 & 0,57 & 0,4 & 6,27 & 1,06 & 0,26 & 0,35 & 44,24 \\
\hline KK \#1385 & & 0,076 & 66,11 & 0,006 & 0,043 & 0,36 & 0,21 & 0,3 & 027 & 6,89 & 0,94 & 0,2 & 0,16 & 24,17 \\
\hline KK \# 137 & & 0,87 & 39,64 & 1,08 & 0,061 & 0,3 & 1,67 & 2,84 & 1,41 & 7,56 & 0,98 & 0,95 & 0,3 & 42,18 \\
\hline KK \#480 & \multirow[t]{5}{*}{ group 5} & 3,05 & 39,12 & 5,24 & 0,052 & 0,26 & 12 & 0,68 & 0,74 & 3,95 & 1,23 & 0,14 & 0,58 & 43,56 \\
\hline Crines 22 & & 0,43 & 39,94 & 0,0058 & 0,02 & $0,2 z$ & 0,19 & 3,27 & 0,75 & 8,14 & 2,08 & 0,54 & 0,87 & 43,49 \\
\hline KK \#461 & & 0,04 & 42,49 & 0,0076 & 0,059 & 0,36 & 0,08 & 0,45 & 3,1 & 8,54 & 1,11 & 0,52 & 0,23 & 42,76 \\
\hline KK \# & & $1, \infty 8$ & 29,74 & 0,065 & 0,031 & 0,32 & 0,39 & 0,49 & 0,22 & 7,37 & 1,04 & 0,41 & 0,37 & 57,31 \\
\hline KK \#354 & & 1,09 & 55,32 & 0,043 & 0,026 & 0,21 & 0,18 & 025 & 0,44 & 4,92 & 0,64 & 0,12 & 0,16 & 36,11 \\
\hline KK \#261 & \multirow[t]{3}{*}{ group 6} & 0,01 & 42,11 & 0,045 & 0,034 & 0,35 & 0,27 & 0,56 & 4,57 & 6,99 & 0,98 & 0,69 & 0,13 & 43,22 \\
\hline KK \#414 & & 0,17 & 49,86 & 0,006 & 0,043 & 0,37 & 0,12 & 0,56 & 3,57 & 7,12 & 0,88 & 0,37 & 0,33 & 36,4 \\
\hline KK \#90 & & 0,026 & 41,38 & 0,0005 & 0,031 & 0,26 & 0,05 & 029 & 3,12 & 6,35 & 0,83 & 0,25 & 0,21 & 46,89 \\
\hline KK \#329 & \multirow[t]{3}{*}{ group 7} & 0,004 & 32,95 & 0,0005 & 0,046 & 0,28 & 0,06 & 0,63 & 127 & 7,94 & 1,08 & 0,78 & 0,59 & 54,21 \\
\hline KK $\# 236$ & & 1,59 & 42,23 & 1,46 & 0,052 & 0,37 & 0,49 & 0,46 & 0,82 & 6,37 & 0,89 & 0,23 & 0,35 & 44,56 \\
\hline Crimea 38 & & 0,86 & 46,05 & 0,000 & 0,056 & 0,45 & 2,00 & 4,34 & 0,59 & 7,55 & 2,43 & 1,65 & $0,7 x^{2}$ & 33,03 \\
\hline KK \#19 & \multirow[t]{7}{*}{ group 8} & 0,25 & 56,54 & 0,046 & 0,036 & 0,55 & 3,18 & 1,92 & 1,12 & 7,91 & 1,01 & 0,84 & 0,32 & 25,98 \\
\hline Crimen 46 & & 0,7 & 51,34 & 0,038 & 0,003 & $Q, 34$ & 0,045 & 0,27 & 0,25 & 1,55 & 1,64 & 0,15 & 0,5 & 42,85 \\
\hline KK $\# 535$ & & 0,1 & 51,92 & 0,033 & 0,023 & 0,3 & 0,09 & 0,35 & 0,43 & 7,75 & 0,84 & 0,15 & 0,23 & 37,66 \\
\hline KK \#376 & & 0,51 & 53,48 & 0,0076 & 0,053 & 0,39 & 0,57 & 0,82 & 0,69 & 8,13 & 0,88 & 0,2 & 0,25 & 33,51 \\
\hline Crimea 19 & & 2,05 & 37,75 & 0,009 & 0,05 & 0,32 & 0,05 & 3,97 & 3,79 & 6,15 & 1,04 & 0,59 & 0,35 & 43,75 \\
\hline KK \#38 & & 0,019 & 36,32 & 0,24 & 0,73 & $0,2 ?$ & 0,041 & 0,92 & 329 & 7,37 & 0,99 & 0,1 & 0,23 & 49,22 \\
\hline KK \#3 & & 0,049 & 49,27 & $0, \infty 11$ & 0,027 & 0,31 & 0,37 & 0,61 & 6,68 & 4,72 & 0,66 & 0,12 & 0,044 & 36,75 \\
\hline Sepai \#44 & & 1,08 & 46,19 & 0,09 & 0,056 & 0,7 & 1,03 & 3,92 & 5,01 & 6,05 & 0,87 & 2,04 & 0,72 & 31,26 \\
\hline Sepai \#59 & & 1,81 & 58,25 & 0,062 & 0,11 & 0,59 & 0,25 & 3,58 & 4,72 & 6,54 & 0,94 & 2,38 & 1,15 & 19,13 \\
\hline \begin{tabular}{|l|l|} 
speroko rous \\
\end{tabular} & & 1,69 & 43,12 & 2,86 & 0,041 & 0,32 & 0,16 & 3,32 & 6,81 & 2,49 & 1,35 & 2,18 & 6,12 & 29,33 \\
\hline
\end{tabular}

Table 1. Chemical composition of glaze samples of Kazan Kremlin, the Crimea and Bolgar (major and minor elements, $\%)$.

\begin{tabular}{|c|c|c|c|c|c|c|c|c|c|c|c|c|c|c|c|c|c|c|c|c|}
\hline samp & & As & D & $\mathrm{Ba}$ & $\mathrm{Be}$ & $\mathrm{Bi}$ & Co & & $\mathrm{Ga}$ & Li & $\mathrm{Nb}$ & $\mathrm{Ni}$ & $\mathrm{Sb}$ & Sc & $\mathrm{Sr}$ & $v$ & $\bar{Y}$ & $\mathrm{Yb}$ & $\mathrm{Zn}$ & $\mathrm{Zr}$ \\
\hline KK & \multirow{2}{*}{ gobe } & & \begin{tabular}{|l|}
66 \\
\end{tabular} & 350 & 1,6 & 0,9 & 5,5 & 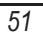 & \begin{tabular}{|l|}
7 \\
\end{tabular} & 35 & 7 & 230 & 0 & - & 70 & \begin{tabular}{|l|l|}
82 \\
\end{tabular} & 16 & 1,5 & 65 & 71 \\
\hline Crimea 8 & & 19 & 320 & 350 & 2,5 & 1,1 & 11 & 2 & 13 & 28 & 17 & 51 & 7,5 & & 80 & 170 & 13 & 2,5 & 28 & 94 \\
\hline$\overline{K K}$ & \multirow{5}{*}{ group 1} & 90 & \begin{tabular}{|l|}
46 \\
\end{tabular} & 460 & 1,5 & 0,7 & 5 & 61 & 12 & 25 & 7 & 380 & 11 & & 80 & 150 & 15 & 1,9 & 88 & 89 \\
\hline KK & & 16 & 39 & 280 & 1,6 & 1,9 & 9,5 & 43 & $y$ & 31 & 6 & 330 & 2 & $\overline{4}$ & 60 & 110 & 14 & 2 & 6 & 76 \\
\hline & & 25 & 180 & 310 & 1,8 & $\begin{array}{ll}18 \\
\end{array}$ & 21 & 65 & 13 & 26 & 7 & 380 & 4 & 5 & 80 & 160 & 10 & 1,4 & 5 & 45 \\
\hline $\mathrm{Kr}$ & & 16 & 28 & 290 & 1,6 & $\begin{array}{ll}1,7 \\
\end{array}$ & 2,5 & 71 & 19 & 41 & 11 & 250 & 41 & 1. & 60 & 180 & 21 & 2,5 & 9 & 85 \\
\hline & & - & \begin{tabular}{|l|}
54 \\
\end{tabular} & 390 & 1,1 & 0,8 & 8 & 52 & 14 & 25 & 7 & 290 & 21 & & 50 & 130 & 11 & 1,8 & 680 & 140 \\
\hline & \multirow{2}{*}{ up } & 4 & 31 & 260 & 1,1 & 0,8 & 4 & 92 & 10 & 27 & 8 & 36 & 35 & & 70 & 140 & 9 & 0,6 & 870 & 80 \\
\hline КК\#403 & & 20 & 140 & 390 & 1,8 & 1 & 10 & 53 & \begin{tabular}{|l|}
17 \\
\end{tabular} & 26 & 9,2 & 89 & 95 & 9,1 & 130 & 150 & 19 & 2,3 & 410 & 92 \\
\hline
\end{tabular}




\begin{tabular}{|c|c|c|c|c|c|c|c|c|c|c|c|c|c|c|c|c|c|c|c|c|}
\hline Crimea 26 & & 29 & 350 & 490 & 2,3 & 1,4 & 15 & 79 & 35 & 56 & 14 & 32 & 19 & 21 & 140 & 110 & 19 & 2,7 & 73 & 130 \\
\hline КК \#42 & & 32 & 65 & 510 & 2,8 & 1,3 & 8,7 & 63 & \begin{tabular}{|l|l|}
18 \\
\end{tabular} & 35 & 12 & 26 & 9,6 & 16 & 120 & 120 & 21 & 2,4 & 53 & 190 \\
\hline КК\#1гл & & 34 & 180 & 520 & 2,6 & 1,6 & 15 & 66 & 23 & 28 & 8,2 & 21 & 92 & 13 & 100 & 180 & 14 & 2,9 & 90 & 30 \\
\hline KK\#266 & & 21 & 61 & 490 & 2,5 & 11 & 11 & 59 & 21 & 25 & 7,8 & 32 & 94 & 11 & 210 & 320 & 13 & 2,3 & 55 & 87 \\
\hline KK\#137 & & 14 & 41 & 210 & 1,1 & 3,1 & 6 & 28 & 9 & 26 & 8 & 71 & 25 & 6 & 70 & 76 & 14 & 1,5 & 69 & 91 \\
\hline KK \#43 & \multirow{4}{*}{ oup 3} & 4 & 26 & 250 & 1,7 & 0,9 & 3,1 & 32 & 9 & 43 & 10 & 60 & 150 & 1,2 & 100 & 64 & 11 & 1,5 & 42 & 93 \\
\hline Crimea 10 & & 86 & 280 & 390 & 2,1 & 1,3 & 35 & 54 & 23 & 43 & 17 & 13 & 280 & 7 & 150 & 61 & 16 & 2,8 & 96 & 81 \\
\hline KK \#932 & & 16 & 31 & 290 & 1,3 & 0,9 & 13 & 59 & 8 & 26 & 7 & 86 & 150 & 6 & 60 & 71 & 21 & 2,5 & 96 & 78 \\
\hline KK\#311 & & 19 & 46 & 270 & 1,4 & 5,6 & 4 & 31 & 7 & 23 & 9 & 76 & 350 & 4 & 80 & 43 & 12 & 1,5 & 49 & 76 \\
\hline КК\#1501 & \multirow{6}{*}{ group 4} & 110 & 78 & 330 & 2,1 & 8,7 & 7,5 & 71 & 15 & 28 & 8,9 & 23 & 1800 & 12 & 88 & 330 & 9,1 & 2,1 & 54 & 110 \\
\hline Crimea 51 & & 14 & 460 & 350 & 2,3 & 2,4 & 24 & 190 & 36 & 46 & 19 & 88 & 1070 & 18 & 190 & 200 & 32 & 3,6 & 37 & 290 \\
\hline КК \#185 & & 24 & 62 & 290 & 2 & 1,6 & 6 & 58 & 18 & 26 & 8,4 & 75 & 330 & 5,4 & 120 & 260 & 11 & 2,9 & 51 & 180 \\
\hline KK \#32 & & 39 & 24 & 250 & 1,4 & 1,4 & 2,5 & 34 & 11 & 24 & 8 & 59 & 200 & 2,5 & 75 & 150 & 13 & 2 & 67 & 85 \\
\hline KK\#1385 & & 11 & 15 & 160 & 1,1 & 1,1 & 2,8 & 85 & 7,5 & 23 & 6,4 & 74 & 260 & 3,6 & 90 & 140 & 9 & 1,4 & 78 & 79 \\
\hline KK \# & & 21 & 59 & 380 & 1,8 & 6,5 & 4,5 & 130 & 15 & 31 & 8 & 27 & 110 & 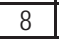 & 210 & 110 & 15 & 2,1 & 180 & 59 \\
\hline KK \#480 & \multirow{5}{*}{ group 5} & 7 & 19 & 140 & 0,9 & 2,8 & 2,5 & 25 & 7 & 26 & 7 & 270 & 280 & 2 & 50 & 61 & 8 & 0,8 & 180 & 38 \\
\hline Crimea 22 & & 400 & 130 & 610 & 3,2 & 2 & 10 & 61 & 21 & 72 & 25 & 150 & 790 & 14 & 200 & 73 & 20 & 2,3 & 210 & 150 \\
\hline KK \#461 & & 14 & 36 & 190 & 1 & 0,7 & 7,5 & 61 & 13 & 28 & 7 & 120 & 260 & 3 & 60 & 36 & 8 & 1,7 & 250 & 90 \\
\hline KK \#58 & & 11 & 48 & 270 & 1,1 & 7,5 & 5 & 42 & 10 & 25 & 8 & 360 & 190 & 5 & 60 & 51 & 14 & 2,1 & 61 & 71 \\
\hline KK\# & & 8 & 30 & 140 & 1,1 & 2,7 & 2,2 & 50 & 7 & 25 & 5 & 140 & 120 & 3 & 70 & 110 & 9,5 & 1,5 & 23 & 77 \\
\hline KK \#261 & \multirow{3}{*}{ group 6} & 13 & 58 & 280 & 1,7 & 1,2 & 7 & 58 & \begin{tabular}{|l|l|}
13 \\
\end{tabular} & 21 & 13 & 430 & 11 & 9 & 50 & 71 & 21 & 2,8 & 70 & 190 \\
\hline KK \#414 & & 5 & 43 & 280 & 1,2 & 0,8 & 7,5 & 180 & 15 & 27 & 8 & 370 & 36 & 8 & 80 & 73 & 24 & 2,3 & 580 & 96 \\
\hline KK: & & 2 & 32 & 200 & 0,9 & 1,2 & 5,8 & 140 & 8,4 & 30 & 6 & 170 & 14 & 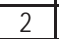 & 53 & 38 & 7,4 & 1,6 & 34 & 82 \\
\hline KK\#329 & \multirow{3}{*}{ group 7} & 7 & 62 & 340 & 1,6 & 43 & 5,5 & 71 & 10 & 29 & 11 & 290 & 10 & 2 & 70 & 48 & 19 & 2,9 & 68 & 130 \\
\hline KK \#236 & & 47 & 29 & 210 & 1,4 & 42 & 2,6 & 38 & 10 & 24 & 9 & 120 & 37 & 4 & 70 & 170 & 11 & 1,5 & 55 & 71 \\
\hline Crime & & 100 & 380 & 570 & 3 & 119 & 12 & 60 & 16 & 45 & 22 & 150 & 60 & 18 & 180 & 120 & 20 & 3 & 64 & 110 \\
\hline КК\#19 & \multirow{7}{*}{ group 8} & 19 & 61 & 450 & 3,2 & 190 & 4,8 & 49 & 16 & 38 & 7,1 & 28 & 780 & 7,4 & 160 & 110 & 8,9 & 2,1 & 340 & 110 \\
\hline Crimea 46 & & 120 & 520 & 99 & 1,1 & 115 & 8,7 & 58 & 27 & 45 & 11 & 21 & 2900 & 4,9 & 81 & 84 & 13 & 1,1 & 66 & 38 \\
\hline KK \#535 & & 8 & 59 & 310 & 1,5 & 54 & 3,5 & 52 & \begin{tabular}{|l|l|}
14 \\
\end{tabular} & 38 & 8 & 130 & 130 & 7 & 90 & 82 & 17 & 1,8 & 70 & 86 \\
\hline КK\#376 & & 2 & 35 & 260 & 1,6 & 52 & 5 & 32 & 8 & 29 & 8 & 51 & 160 & 7 & 100 & 120 & 14 & 1,9 & 37 & 84 \\
\hline Crimea 19 & & 23 & 630 & 430 & 2,4 & 39 & 18 & 510 & 16 & 46 & 14 & 280 & 270 & 13 & 96 & 130 & 16 & 2 & 78 & 46 \\
\hline KK \#38 & & 25 & 43 & 570 & 1,7 & 24 & 7,5 & 32 & 9 & 27 & 9 & 180 & 130 & 4 & 120 & 25 & 14 & 2,3 & 68 & 120 \\
\hline KK \#3 & & 2 & 13 & 130 & 1 & 21 & 6 & 12 & 8 & 32 & 8 & 49 & 130 & 3 & 60 & 21 & 8 & 1,8 & 54 & 80 \\
\hline Sepai \#44 & & 320 & 46 & 650 & 2,2 & 3,5 & 13 & 45 & 18 & 31 & 6,8 & 74 & 1700 & 12 & 170 & 84 & 12 & 2,1 & 84 & 95 \\
\hline Sepai \#59 & & 390 & 92 & 350 & 2,3 & 2,1 & 8,3 & 48 & 19 & 32 & 8,2 & 78 & 2300 & 7,5 & 85 & 110 & 9,4 & 2,2 & 79 & 91 \\
\hline oherokonus & & 0,87 & 16 & 2,9 & 0,99 & 91 & 0,82 & 2,5 & \begin{tabular}{|l|}
1,2 \\
\end{tabular} & 4,2 & 0,62 & 3,2 & 45 & 0,12 & 2,9 & 2,8 & 0,85 & 0,85 & \begin{tabular}{|l|}
0,41 \\
\end{tabular} & 0,72 \\
\hline
\end{tabular}

Table 2. The chemical composition of glaze samples of Kazan Kremlin, the Crimea and Bolgar (trace elements, ppm).

Antimony (one tenth of a percent) and tin (one hundredth of a percent) are the impurities to the lead component in glaze samples of different territorial localization. It may be noted that a similar structure is shown by V.V. Bulgakov for glazed ceramics from Sudak (Bulgakov, 2005).

The comparative analysis of the obtained results and of chemical composition of glazed ceramic ware from the large production center of Kadikalesi was carried out for the purpose of identification of origin of technological school. This vocational school has existed in Turkey in the late $17^{\text {th }}$ - early $18^{\text {th }}$ centuries (Bizantibe, 2013). Turkish researchers relate this production with the traditions of the Byzantium and attribute this type of pottery to the zeuxippus (tseiksipus) type. The study showed that ceramics glaze of Kazan Kremlin is similar to the glaze from Kadikalesi.

According to analytical data, "lead" recipe with a lead content of $40-60 \%$ was used in production of Turkish, Crimean and Bolgar glaze and it is corresponding to the samples from Kazan Kremlin. Table 3 shows the content of the main elements in the artifacts glaze from Kadikalesi, also there are results of analysis of the Crimean Funy ceramics and glassy sags from Bolgar ancient settlement sepai for comparison. Copper content exceeds $1 \%$ in Bolgar glaze, as in so many of Kazan samples, i.e. this component acts as a dye. It may be noted that the same dye was also used by the Turkish and Crimean medieval ceramists (Table 3). 
Table 3. Comparison of macro-element composition of lead glaze (Data of Turkey ceramics, Bizantibe, 2013)

\begin{tabular}{|c|c|c|c|c|c|c|c|c|c|c|c|c|c|c|}
\hline lab.№ & & $\mathrm{PbO}$ & $\mathbf{S n O}$ & $\mathrm{Ti}_{2} \mathrm{O}$ & $\mathrm{P2O}_{5}$ & $\mathrm{CaO}$ & $\mathrm{Fe}_{2} \mathrm{O3}$ & $\mathrm{Al}_{2} \mathrm{O}_{3}$ & $\mathrm{~K}_{2} \mathrm{O}$ & $\mathrm{MgO}^{\mathrm{N}}$ & $\mathrm{Na}_{2} \mathrm{O}$ & $\mathrm{SiO}_{2}$ & $\mathrm{CuO}$ & $\mathrm{MnO}$ \\
\hline & Turkey & 47,42 & & & & 2,14 & 1,09 & 3,97 & & 0,87 & 0,34 & 40,32 & 3,1 & 0,22 \\
\hline & Turkey & 52,65 & & & & 2,02 & 3,56 & 5,12 & 0,51 & 0,77 & 0,33 & 35,54 & & \\
\hline & Turkey & 60,3 & & & & 2,3 & & 7,2 & & 1,1 & 0,6 & 28,5 & & \\
\hline 50 & 51 Crimea & 42,58 & 0,061 & 0,87 & 0,05 & 4,18 & 1,15 & 7,84 & 1,92 & 1,29 & 0,7 & 38,95 & 0,11 & 0,048 \\
\hline 44 & 45 Crimea & 49,77 & 0,11 & 0,61 & 0,08 & 4,35 & 2,91 & 7,62 & 1,95 & 1,39 & 0,94 & 27,52 & 2,34 & 0,044 \\
\hline 38 & 39 Crimea & 52,15 & 0,02 & 0,5 & 0,05 & 2,2 & 0,74 & 7,85 & 1,49 & 1,28 & 0,59 & 31,68 & 1,25 & 0,04 \\
\hline 27 & sepai 44 & 46,19 & 0,09 & 0,7 & 1,63 & 3,92 & 5,01 & 6,05 & 0,87 & 2,04 & 0,72 & 31,26 & 1,08 & 0,056 \\
\hline 28 & sepai 59 & 58,25 & 0,062 & 0,59 & 0,25 & 3,58 & 4,72 & 6,54 & 0,94 & 2,38 & 1,15 & 19,13 & 1,81 & 0,11 \\
\hline
\end{tabular}

Figure 2 shows charts of a lead oxides ratio, aluminum, nickel and antimony. Unfortunately, the Turkish samples were analyzed by X-ray fluorescence method that does not give information about impurities, so we had no opportunity to carry out the comparative analysis on all elements. However, the fact of analogy of ceramics glaze composition of Kazan Kremlin, Kadikalesi, the Crimea and Bolgar is obvious.

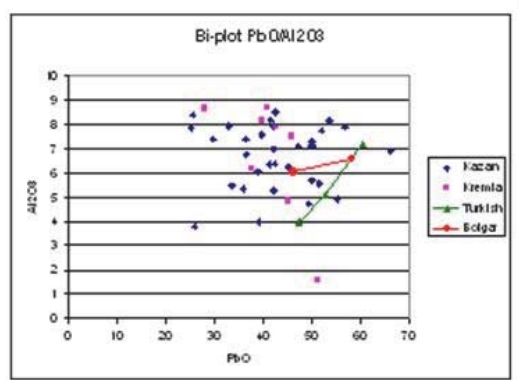

a.

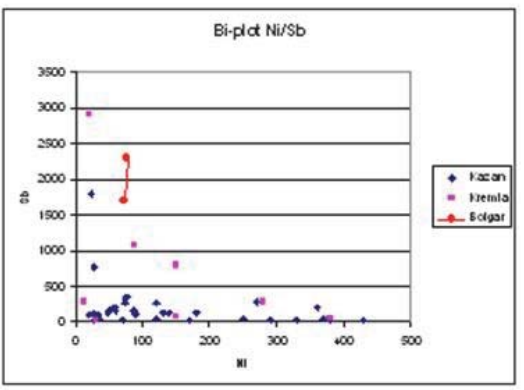

b

Figure 2. Bi-plot of (a) - $\mathrm{PbO}: \mathrm{Al}_{2} \mathrm{O}_{3}$, (b) - Ni:Sb relation

\section{Conclusion}

The tradition of glazed pottery accounts for several millennia (Gulmini et. al., 2013). The first lead glaze (45-60\%) appeared in Europe at the beginning of the first millennium (De Benedetto et. Al., 2004). Researches (Gulmini et. Al., 2013; Maltoni et. Al., 2012) show that in the $10^{\text {th }}-12^{\text {th }}$ centuries glazed ceramics with lead glaze were produced in various regions of the Mediterranean and Europe, in the Middle East (Afghanistan). Samples from Kazan belong to this type of ceramics.

The conducted researches showed that the ceramics glaze compounding from excavations of the Kazan Kremlin is identical to Turkish and Crimean compounding. The glaze was prepared from lead and sand-clay mixtures in various ratios from 2: 1 to 1: 3. According to the analytical data (Gulmini et. al., 2013) glaze of Afghan samples has low content of aluminum. The concentration of this element in Italian samples is 4-7\% (Maltoni et. al., 2012) which is similar to Kazan, Turkish, Crimean and Bolgar samples.

According to the researches, the most informative method is the emission spectrum analysis which allows determining both main and minor and trace elements (Sitdikov and Khramchenkova, 2015). The comparison of glaze composition gives interesting analytical data that allows finding sources of raw materials production (Khramchenkova, 2014). Specific groups of antimony, bismuth and nickel in the studied samples are likely determined by the raw source of lead. Based on this, it is possible to assume that the raw sources of lead for the glaze production in Kazan Kremlin and the Crimean peninsula were the same. This assumption can be also carried to the Bolgar samples.

Given the time of samples production, it is possible to notice the following stages. The center of production of glazed ceramics in Turkey is dated by the 12-13 centuries.

Glazed pottery was produced in the Crimea actively in the $13^{\text {th }}-14^{\text {th }}$ centuries. For some reason these complexes of commercial production of glazed pottery ceased to exist. Kazan ceramics is dated by the $13^{\text {th }}-14^{\text {th }}$ centuries. Thus, 
possible "migration" of technology of ceramic ware glazing from Turkey to the Crimea, and then in some other centers is observed. Perhaps, this center became the supplier of ceramic ware for the Kazan Khanate. The question of determining the location of this industrial complex is the task of further researches.

\section{Acknowledgments}

The work is performed at the expense of the subsidy funds provided by the state support of Kazan (Volga) Federal University in order to increase its competitiveness among the world's leading scientific and educational centers. The authors thank S.G. Bocharov for providing archaeological samples from the Crimean production centers.

The work is performed according to the Russian Government Program of Competitive Growth of Kazan Federal University.

\section{References}

Bulgakov, V.V. (2005). Glazuri severo-prichernomorskoj polivnoj keramiki XIII-XV vv. Krymskij f-I IA NAN Ukrainy, 359-378.

Koval', V. Ju. (2009). Himicheskij sostav glazurej srednevekovyh fajansov. Donskie drevnosti, 10, 209-237.

Kokorina, N.A. (1999). Keramika usad'by gonchara is Iski Kazani. Tatarskaja arheologija 1-2, 70-71.

Khramchenkova, R.Kh. (2014) Himicheskij sostav glin kak indicator syr'evogo istochnika. Povolzhskaja arheologija, 2 (8), 176-205.

Bizantibe Craftsmen - Latin Productions (2013). Istanbul. Zero Producksiyon, 87.

De Benedetto, G.E., Acquafredda, P., Masieri, M., Quarta, G., Sabbatini, L., Zambonin, P.G., Tite, M. \& Walton, M. (2004). Investigation on Roman lead glaze from Canosa: results of chemical analyses. Archaeometry, 46, 615-624.

Forster, N., Grave, P., Vickery, N., Kealhofer, R. (2001). Non-destructive analysis using P-XRF: methodology and application to archaeological ceramics. X-Ray spectrometry 40, 389-398.

Gulmini, M., Giannini, R., Lega, A.M., Manna, G., Mirti, P. (2013). Ghaznavid glazed pottery from Bust and Lanshar-i Bazar (Afganistan). Archaeometry 55 (4), 569-587.

Halikov, A.H.(1989). Arheologicheskie nabljudenija na predbulachnoj chasti posada Kazani XV-XVI vekov. Arheologicheskie otkrytija Urala i Povolzh'ja. Syktyvkar.

Maltoni, S., Silvestri, A., Maritan, L. \& Molin, G. (2012). The Medieval lead-glazed pottery from Nogara (north-east Italy): a multimethodological study. Journal of Archaeological Science 39, 2071-2078. http://www.sciencedirect.com/science/journal/03054403

Sitdikov, A.G., Khramchenkova, R.Kh. (2015). Typology of Glazed Ceramics of the Kazan Khanate and Analysis of Its Element Composition. Journal of Sustainable Development 8 (7), 234-244.

Wedepohl, K.H., Krueger, I. \& Hartmann, G. (1995). Medieval lead glass from northwestern Europe. Journal of Glass Studies 37, 65-82. 